ISBN 978-93-84468-75-0

International Research Conference on Literature, Humanities and Sociology (RCLHS-2016)

Oct.11-12, 2016 at Dubai (UAE)

\title{
Understanding Old Age through the character of Ebenezer Scrooge: A Review
}

\author{
Thushara Mariam Thomas ${ }^{1}$ and Deepti S. ${ }^{2}$ \\ ${ }^{1}$ Student, Dept. of Psychology, Jain University \\ ${ }^{2}$ Research Scholar, Dept. of Psychology, Jain University
}

\begin{abstract}
Previously, many attempts to bring together Psychology and Literature were made and a similar attempt has been made in this paper. The main focus of this paper is to understand a famous literary character using theories of human development. The current paper is a review article that aims to analyze the character of Ebenezer Scrooge from the famous novella 'A Christmas Carol' by Charles Dickens. The character analysis includes a psychological approach where three theoretical perspectives pertaining to old age were used to understand the character of Scrooge. The theories included are-Erikson's Psychosocial Stages of Personality Development, Socioemotional Selectivity Theory and Disengagement Theory versus Activity Theory of Successful Aging. The transformation of the character of Scrooge has also been traced using these theories. Scrooge is seen as an individual who at the beginning of the novella is in a state of ego integrity, but slowly moves to a state of despair as it progresses and then slowly begins to attain ego integrity at the end. From being disengaged, he starts becoming active in life as the novella progresses. He begins to take an interest in situations that are emotional in nature.
\end{abstract}

Keywords: Scrooge, Psychological Analysis Human Development, Old Age

\section{Introduction}

Literature has provided us with numerous characters with a varied range of behavior. Literature and literary characters are results of human imagination whereas Psychology is the study of human behavior. Various attempts to understand the connection between Psychology and Literature has been undertaken previously. Some authors have suggested the benefits of applying Psychology to literary criticism. Hoffman (1957), has put forth how Freud's concepts of id, ego and superego can especially be made use of for literary criticism. He has further stated how metaphors, a figure of speech, can be considered as an equivalent to and also an elaboration of the concepts of id, ego and superego. Using Psychology for literary criticism can be considered as an attempt to bring the two distinct areas of Psychology and Literature together. The current paper is also an attempt at interconnecting these two areas by making use of various theoretical perspectives in Psychology to understand the well-known literary character of Ebenezer Scrooge from Charles Dickens' famous novella- A Christmas Carol. When we see how quickly we can contextualize Scrooge's characteristics with developmental theories of old age, we can see how we can closely ally the two seemingly diverse fields. One of the advantages can be to see what methods are employed by characters to get over specific obstacles and can test them to see if these methods can be used as psychological interventions.

Many literary works have psychological themes embedded in them. Shakespearean plays are well-known for their psychological insights into various aspects of behavior. Various instances of a disturbed psyche have also been portrayed in many of his plays- for example, the scene from the play 'Macbeth' where Lady Macbeth is hallucinating the presence of blood drops on her hands and trying to wash them off. Some of his famous 
characters have also been analyzed deeply especially from a psychological point of view. Many attempts to understand the thought processes of characters such as Macbeth and Hamlet have been made. Byles (2005) in his essay, has adopted Freud's theory of Psychoanalysis and his concepts of Eros and superego to understand Hamlet's revenge.

Paris (1997), in his book 'Imagined Human Beings: A Psychological Approach to Character and Conflict in Literature', has stated that various critics have opined that it is impossible to understand literary characters from a psychological viewpoint. He further states that it has been a grave mistake to reject a psychological analysis of literary characters. Paris has made use of Karen Horney's Psychoanalytic Theory to understand various characters and literary texts such as Antigone, Hedda Gabler, A Merchant of Venice, Jane Eyre, Wuthering Heights, A Doll's House, Great Expectations etc. For many years, Paris has been trying to bring about a psychological approach to understand literary characters in the same manner as people have tried to understand real human beings using Psychology. This calls for more attempts to understand various literary characters from a psychological point of view. Analyzing a character from a psychological viewpoint, helps gain deeper understanding into the thought processes of the character. As literary characters are the offshoots of human imagination, the behaviors portrayed by them are more often than not similar to the behavior of human beings in a real-life situation. Quoting Paris (1997), "These characters are not flesh and blood creatures, of course, but are imagined human beings who have many parallels with people like ourselves." Therefore, such attempts to psychologically analyze characters can be further applied to understand certain behaviors of common people and the causes for such behaviors in a real-life setting. This also states how literary texts can be useful sources to understand human behavior and there is a need to take up more and more attempts to understand human behavior using Literature.

A crisis situation is present in all literary works. The characters in them either successfully resolve their problems or succumb to it. When a character is able to resolve a problem, there are various techniques used that help in the process of recovery. Psychological intervention includes certain techniques that help a client overcome his/her problems. Techniques used in a literary work can be elaborated or modified in such a manner that they can serve as a basis for developing a psychological intervention technique. Carefully analyzing literary texts can therefore, help in the intervention process. This highlights yet another reason as to why it is important to psychologically analyze literary characters. Bibliotherapy is a new form of intervention which involves the use of books and reading as an intervention technique in the treatment of psychological disorders. This technique helps the person to attain catharsis through reading. Also, the behaviors and techniques used by a literary character, can help the person overcome their problems. The person may also adopt a similar technique to deal with the issues they are facing. This further stresses upon the relationship between Psychology and Literature and also the need to connect these two domains more.

Positive Psychology has brought about a shift from the focus on 'what is wrong with the individual' to 'what can be developed'. One of the most recent and widely researched aspect of Positive Psychology includes the concept of Character Strengths as given out by Christopher Peterson and Martin Seligman. There are 24 character strengths that an individual can possess and these strengths can be developed in order to help an individual function efficiently. It can help an individual become the best he or she can be and become more productive by imbibing these strengths in one's life. Focusing on this strengths during intervention also gives a positive outlook towards the problem rather than only focusing the negative aspect of the problem. In the end of the novella, Scrooge begins to revive his familial relationships and also shows kindness towards other fellow beings. Taking the concept of character strengths into consideration, we can see two such strengths of love and kindness that emerges in Scrooge that helps him become a better person.

"There is not much point in writing a novel unless you can show the possibility of moral transformation, or an increase in wisdom, operating in your chief character or characters"

- Antony Burgess 
A Christmas Carol is a famous novella written by Charles Dickens in 1843. A story of a miserly old manEbenezer Scrooge and his transformation, brought about by three Spirits, from being selfish to a kind hearted man forms the storyline of this well-known novella. A Christmas Carol is a popular book even after 170 years of its publication. An attempt to analyze the character of Scrooge has been made by Eveland (2005). She made an effort to understand Scrooge as a mentally disturbed client who visits a psychologist. She has also written a case history of Scrooge and analyzed the problems using the multi-axial system of classification of mental disorders. Furthermore, Williams (2011), has attempted to understand the character of Scrooge using Alfred Adler's theory of individual Psychology. According to him, the transformation in Scrooge's character that was brought about by the three spirits, is similar to the process of Adlerian form of therapy. The current paper attempts to analyze the character of Scrooge using some of the famous theories of Life-Span Development. As the focus of the paper is on Ebenezer Scrooge, an old man, the theories that have been chosen are those pertaining to old age, which helps us understand better the mindset of those individuals who are in this phase of their lives.

Ebenezer Scrooge is a miserly old man disliked by all. On a Christmas Eve, in his apartment, Scrooge is visited by the Ghost of Marley, his business partner. In order to prevent Scrooge from having the same fate as him, of being condemned to wander the Earth bounded by chains, he announces that three Spirits would be visiting Scrooge in an attempt to change his present behavior.

The first spirit that visits Scrooge is the Ghost of Christmas Past. Scrooge is taken on a journey through his early life. Scrooge revisits his childhood days, days of apprenticeship and his long-lost love life. These scenes move Scrooge deeply and he is seen crying in regret. He is then visited by the Ghost of Christmas Present who takes him around London to show what Christmas is to the other people. He also catches a glimpse of his assistant Bob Cratchit's dwelling and the party at Scrooge's nephew's house. At the end of the day, Scrooge sees two children, Ignorance and Want, who are starved and are living under the Ghost's coat. Finally, the Ghost of Christmas Yet to come shows scenes of a man's death and the unsympathetic reaction of people to the news of this man's death. Painfully, Scrooge realizes that he is the dead man. This brings about a lot of change in Scrooge's character. Scrooge transforms into an entirely new person by the end of the novella.

\section{Analysis}

1. Erikson's Psychosocial Stages of Personality Development: Ego integrity vs Despair

According to Erikson's lifespan approach, the last stage of psychosocial development is ego integrity vs despair. This stage applies to those above 55 years of age. This stage focuses on reflections during old age about how one has lived one's life. The main question asked is "Did I live a meaningful life?" When a person is satisfied with the life they have lived and feels that he or she has coped with the difficulties and successes in life, the person is said to possess ego integrity. When a person feels frustrated or angry about their life's happenings, they are said to be in a state of despair. They become regretful of the errors they have committed. When the crisis at this stage of life is resolved one obtains wisdom.

The character of Scrooge can be assessed based on this theory which can give insights into old age. In this novella, Scrooge's reflections of his life are brought about by Marley's Ghost and the three Spirits of Christmas Past, Present and Yet to Come. It is through the three scenes of past, present and future that Scrooge reflects on how he has been living all this while. The scenes answer the question on how he has lived his life.

In the beginning of the novella, one can see Scrooge as a person who is satisfied with the miserly life that he has been living. He does not have any regrets about his selfishness, how he sends back the two gentlemen empty handed who come for charity, his unethical demands of his assistant Cratchit, and his lost familial ties with his nephew Fred. As the Spirits show different scenes from Scrooge's life, one can see how despair is mounting up.

'Spirit', said Scrooge, 'show me no more! Conduct me home. Why do you delight to torture me?' 
'No more!' cried Scrooge- 'no more. I don't wish to see it. Show me no more!'

The lines quoted above highlights the despair that is taking place within Scrooge. The gradual change that takes place in him can be seen as the novella progresses. At the end of Stave Four, when Scrooge sees his own neglected grave, he falls down on his knees and weeps. He is utterly dissatisfied with the course his life has taken. He pleads for a chance to undo what he has done in his life so far and asks for a chance to change his fate and promises to change his behavior if he is given a chance.

The novella starts off with Scrooge being in a state of ego integrity. A transition from ego integrity to despair can be seen through the course of the novella. However, at the end, he begins a new life by indulging in activities that would give him pleasure and satisfaction. This indicates that Scrooge is slowly beginning to start treading the path of ego integrity and he would ultimately resolve the conflict of this period of his life. A sense of despair hinders the attainment of wisdom which is the virtue that emerges after the conflict between ego integrity and despair has been resolved. The novella does not end with Scrooge attaining ego integrity. Rather, it ends showing him slowly moving towards ego integrity. Therefore, it is seen that he does not attain wisdom at the end of the novella. However, the ending of the novella gives the readers the hope that Scrooge will ultimately possess ego integrity and attain wisdom by resolving the conflicts he had been through.

\section{Carstensen, Isaacowitz and Charles (1999) Socioemotional Selectivity Theory}

According to this theory, some individuals accept the fact that time is limited while others may appear oblivious to it. When a person understands that time is limited, he or she tries to maximize their emotional experiences. They pay attention to maintain warmth and closeness in relationships and uphold intimacy. The theory also proposes that a greater understanding on time constraint can be observed during old age due to the perceived closeness to death. As a result of which they indulge more in activities that are emotionally satisfying.

Scrooge is seen as a person who is unemotional, uncaring and apathetic. He does not indulge in any activity that is emotionally satisfying. He also does not see any importance in maintaining familial relationships and intimacy. Maintaining relationships and intimacy form an important pathway for emotional satisfaction as proposed by the theory. These, however, fail to become important in the eyes of Scrooge. In Stave One, Scrooge's nephew Fred comes down to Scrooge's office to invite him for Christmas. Scrooge is unhappy to see him and also to be called for Christmas dinner. The following lines by Scrooge gives a hint into the level of disinterest Scrooge holds.

'Nephew!' returned the uncle sternly, 'keep Christmas in your own way, and let me keep it in mine.'

Christmas is an important event which brings together members of a family and is a celebration of love and togetherness. While the whole of London is in a festive mood, it fails to arouse any emotions or excitement in Scrooge.

"Every idiot who goes about with 'Merry Christmas' on his lips should be boiled with his own pudding, and buried with a stake of holly through his heart. He should!"

This very statement by Scrooge shows his dislike for any festivities and his inability to enjoy any type of celebration. Through the course of the novella, Scrooge uncovers certain emotions that he had buried within himself as he grew old. The three Spirits show various scenes from Scrooge's life that are emotionally arousing. Through these, Scrooge understands the importance of relationships and how they are emotionally satisfying. At the end, he understands the importance of emotions. He decides to indulge in certain activities that are emotional in nature. He is seen to be so happy that he sings. He wants to order the biggest turkey for the Cratchit family. He genuinely wishes for the happiness and well-being of Cratchit's children. He increases Cratchit's salary. He revives his familial relationships by going to Fred's party. He is able to spend a happy time among his relatives. $\mathrm{He}$ is willing to spend on charity and asks the gentleman who had visited him the previous day to meet him the following day. These acts become emotionally meaningful to him than leading a miserly life.

\section{Disengagement Theory versus Activity Theory of Successful Aging}


There has been many approaches to understand successful aging. Disengagement theory was proposed by Cumming and Henry (1961). According to these gerontologists, old age is characterized by a gradual decline in various aspects of functioning such as physical activity and social roles. Disengagement takes place mutually by the individual and the society. Scrooge is completely disengaged from the society. This disengagement is however brought about by his personality, therefore, cannot be fully attributed to old age. Though Scrooge is preoccupied with himself from the beginning of the novella, we cannot ascertain that he became like that only because of his miserliness. It can be aging that must have made him become more and more preoccupied with himself and reduced his social engagement. He lives alone without anyone. He does not have any friends. There is no one in the whole town who talks to him. He has slowly lost contact with his family. His regard for his sister who adored him has also declined. He also reduces his contact with Fred, his nephew. There is no one with whom he can celebrate Christmas. He is living in his world of solitude. Research has, however shown that some individuals who are disengaged are also able to adjust well. Therefore, it cannot be ascertained that as Scrooge is disengaged, he is not satisfied.

According to the activity theory, an individual when in old age, obtains satisfaction by actively being involved in various activities. The theory was proposed by Neugarten, Havighurst and Tobin (1968). This theory states that as people age, they find activities that replace their old ones. This can help them develop a sense of purpose. There is a transition seen in Scrooge from being disengaged to being active. He derives more meaning in life by developing a loving relationship with his nephew and his other family members. He takes on the new role of being Uncle Scrooge to his nephew and his family. He wants to be actively involved in the Christmas celebrations and the party taking place in Fred's house. He becomes a reformed owner of Scrooge and Marley's who is sympathetic towards his assistant Cratchit. The novella ends, leaving the readers to believe that Scrooge would age successfully and lead a meaningful and satisfied life.

\section{Conclusion}

The current paper has attempted to bring together the domains of Psychology and Literature. The character of Ebenezer Scrooge, who is a greedy and selfish old man, was analyzed in the paper. The character of Scrooge was analyzed to gain insight into old age- the last phase of human life. The analysis was done using three wellknown theories pertaining to old age- Erikson's Psychosocial Stages of Personality Development, Socioemotional Selectivity Theory and Disengagement Theory versus Activity Theory of Successful Aging. At the beginning of the novella, Scrooge was not unhappy with his life's proceedings. Therefore, he can be seen in a phase of ego integrity. But as the Staves move on, he is in a state of despair. Scrooge does not value relationships and emotions. But as the three Spirits show him how his life has progressed, he regrets for lost familial relationships and emotions. He attempts to give importance to emotions and emotional gestures at the end. From being disengaged from the society in the beginning, he starts being actively involved in life which is seen as a healthy way of aging. This article is an attempt to understand the deeper aspects of human behavior through a literary character. Similar approaches to study other characters can be undertaken to understand different aspects of human life. As the character chosen here is an old man, this review article, therefore helps understand certain aspects of old age. It also provides an application based understanding of these theories.

\section{References}

[1] Bibliotherapy (2016, May 9). Retrieved September 8, 2016 from: http://www.goodtherapy.org/learn-abouttherapy/types/bibliotherapy

[2] Byles, J.M. (2005, August 25). Shakespeare and Psychoanalysis: Tragic Alternatives: Eros and Superego Revenge in Hamlet. Retrieved August 27, 2016 from: http://psyartjournal.com/article/show/montgomery_bylesshakespeare_and_psychoanalysis_tragic_al

[3] Carstensen, L. L., Isaacowitz, D. M., \& Charles, S. T. (1999). Taking time seriously: A theory of socioemotional selectivity. American Psychologist, 54, 165-181. 
[4] Cumming, E., \& Henry, W. (1961). Growing Old. New York: Basic Books

[5] Dickens, C. (1990). A Christmas Carol. NY: Tom Doherty Associates, LLC

[6] Eveland, K. (2005, November). Does My Uncle Scrooge Need Help? A Psychological Evaluation of Ebenezer Scrooge. Retrieved August 25, 2016 from: www.charlesdickensinfo.com/christmas-carol/psychological-evaluationscrooge

[7] Hoffman, F.J. (1957). Psychology and Literature. The Kenyon Review, 19(4), 605-619

[8] Moss, S. (2016, June 28). Socioemotional selectivity theory. Retrieved August 12, 2016 from: http://www.sicotests.com/psyarticle.asp?id=286

[9] Neugarten, B.L., Havighurst, R., \& Tobin, S. (1968). Personality and patterns of aging. Middle age and aging (B. Neugarten ed.). Chicago: University of Chicago Press

[10] Papalia, D.E., Olds, S.W., Feldman, R.D. (2004). Human Development (9th ed.) New Delhi: Tata McGraw-Hill Education Private Limited

[11] Paris, B.J. (1997). Imagined Human Beings: A Psychological Approach to Character and Conflict in Literature. NY: NYU Press.

[12] Schultz, D.P., \& Schultz, E.S. (2013). Theories of Personality (10th ed.). Delhi: Cengage Learning India Private Limited

[13] Williams, G.P. (2011, November). Alfred Adler Psychology and its similarities to 'A Christmas Carol' by Charles Dickens. Retrieved August 27, 2016 from: https://www.yourdocmedical.co.uk/articles/350 